\title{
Role of Islamic Banking during COVID-19 on Political and Financial Events: Application of Impulse Indicator Saturation
}

\author{
Ghulam Ghouse ${ }^{1}$, Aribah Aslam ${ }^{1}$ and Muhammad Ishaq Bhatti ${ }^{2, *(D)}$ \\ 1 Economics Department, University of Lahore, Lahore 55150, Pakistan; \\ Ghulam.ghouse@econ.uol.edu.pk (G.G.); Aribah.aslam@econ.uol.edu.pk (A.A.) \\ 2 La Trobe Business School, La Trobe University, Melbourne, VIC 3083, Australia \\ * Correspondence: i.bhatti@latrobe.edu.au
}

Citation: Ghouse, G.; Aslam, A.; Bhatti, M.I. Role of Islamic Banking during COVID-19 on Political and Financial Events: Application of Impulse Indicator Saturation. Sustainability 2021, 13, 11619. https://doi.org/10.3390/ su132111619

Academic Editor: Alexey Mikhaylov

Received: 28 August 2021

Accepted: 14 October 2021

Published: 21 October 2021

Publisher's Note: MDPI stays neutral with regard to jurisdictional claims in published maps and institutional affiliations.

Copyright: (c) 2021 by the authors. Licensee MDPI, Basel, Switzerland. This article is an open access article distributed under the terms and conditions of the Creative Commons Attribution (CC BY) license (https:// creativecommons.org/licenses/by/ $4.0 /)$.

\begin{abstract}
This paper attempts to detect the unavoidable impacts of COVID-19 on geopolitical and financial events related to Islamic banking and the finance sector in Pakistan. It considers only those major events that triggered imbalances in the equity prices of selected Islamic banks. Employed here is the GARCH model, used to predict the volatility series using daily data from January 2007 to July 2020. The Impulse Indicator Saturation (IIS) helps to identify the structural breaks due to COVID-19, as well as the effects of political and financial events on the returns and volatility series of Islamic banks. The results indicate that all the events due to COVID-19 are significant. While 19 out of 21 political and financial events impacted the returns and volatility series, there were only 2 political events out of 18 that showed no significant effect on the returns and the volatility series. The state's and Islamic banks' policymakers can use these results to build an effective and sustainable financial policy regarding Islamic finance and the banking sector.
\end{abstract}

Keywords: COVID-19; Pakistan; PSX; KSE 100; Islamic banking and finance; volatility; GARCH and IIS procedure

\section{Introduction}

It is well known that equity markets play a significant role in the economic progress of any country, particularly in advanced economies. An economy without an equity market cannot improve equity funding accessibility or attain a stable financial structure. The stock exchange offers companies the facility to increase capital for development through trading shares supplied to investors. When the investors invest their money in share-buying instead of saving, it leads to the wise use of assets. The reason for this is that the money that can be consumed is mobilized and conveyed to endorse business activity. On the other hand, it also brings about changes in all related sectors, such as industry, commerce, and agriculture, leading to economic growth and better efficiency and profitability for firms.

The current COVID-19 pandemic has severely affected the world economy. To mitigate the damage done by this unsuspected crisis, the cost of the total bailout of the world's economies has been estimated at no less than USD 5 trillion, injected as a liquidity booster [1]. It is projected that the potential consequences of this pandemic are far larger than any past crisis [2]. This calls for new research and well-coordinated policy action in response to associated economic circumstances [3]. Following World War II, the unemployment rate increased by almost $2 \%$ because of recession [4,5]. The ongoing COVID-19 crisis appears to have had a far worse impact, derailing the usual patterns of demand and supply, and policy tools (particularly in less developed and developing nations) have been designed to combat the economic consequences [6]. However, few studies have discussed the means to tackle the current crisis, which calls for new policy tools [7]. The conventional financial system was previously devastated by a far less severe financial crisis in 2007-2008 (the Global Financial Crisis). It is no wonder that the economy is grossly impacted now, 
and requires a rescue plan [8]. In this context, the financial system could be harnessed to tackle the ongoing crisis $[8,9]$.

A bank plays the role of a mediator between the saver and investor [10]. The banking sector is well-established in Pakistan, and it contributes to almost three-fourths of the total finance industry [11,12]. According to [13], the banking sector in Pakistan grew rapidly from the 1990s. Similar to the banks in any other developed country, Pakistani banks provide an extensive range of facilities to its customers, such as online banking and online billing, and they are now an intrinsic part of Pakistan's economy. In Pakistan, the stock exchange capitalization of Islamic banks represents a major portion of total market capitalization, i.e., about PKR 2482 billion in June 2018. In Pakistan, 21 Islamic banks are operating, but only 5 are full-fledged Islamic institutions, and the remaining 16 are standalone branches of Islamic and conventional banks. In total, two Islamic banks are listed on the KSE 100. Islamic banking's net investment increased by $4.8 \%$ and reached PKR 529 billion (USD 43.5 million) in June 2018. The breakup of the net investment among pure Islamic banks and the Islamic branches of conventional banks grew by PKR 9 billion (USD 7.3 million) in June 2018. The Pakistan Stock Exchange approved the quotation and listing of two open-ended mutual funds, i.e., the AKD Islamic Income Fund and the AKD Islamic Stock Fund, in June 2018 [14].

Since it is now clear that Islamic banks contribute a large proportion to the PSX, it is evident that any fluctuations in the PSX also affects the Islamic banking sector. Many studies carried out in Pakistan depict the effects of political and social events on its stock market [15-17]. Different studies have explored the effects of financial events on the Pakistani Stock Market [18]. Many studies have examined the impact of terrorism, and salient economic and political events, on the Pakistani stock exchange. Investigators have mostly analyzed the influence of financial events on Pakistan's stock exchange volatility, particularly the occurrence of domestic and extraneous financial shocks [11,18,19].

The figures mentioned above show that the Islamic banking sector contributes a significant portion to the PSX, which means that any financial and political shock in the PSX can also affect the Islamic banking sector. Numerous studies have looked at the influence of political events on the Pakistani stock market [17,18,20-23]. Furthermore, these sorts of studies have explored the effects of a financial event on the Pakistan stock exchange's performance. Most studies evaluated the impact of financial events on stock exchange volatility in the presence of domestic and foreign financial shocks [18,19].

No such study has yet analyzed the impact of COVID-19-related political and financial events on Islamic banks' returns and the volatility of Islamic banks' stock prices. We use Impulse Indicator Saturation rather than the GARCH model to detect structural breaks that have not been explored before. Therefore, this study's main objective is to assess the impact of selected political, financial, and COVID-19-related events on the financial series of Islamic banks in Pakistan. The current study also models the volatility of Islamic bank stock prices. This study selects two major Islamic banks, which are on the highly ranked and reputable index KSE 100 of the Pakistan stock exchange (PSX): Bank Islamic Pakistan Limited (BIPL) and Meezan Bank Limited (MEBL). Not only are the selected events up to date, but the current data (in the ongoing pandemic) also add to the novelty of this study. The findings could offer answers to current policy needs. Studies have been published on political structure, but their focus is merely on changes in government. This study is unique in that it explores the impacts of COVID-19 and political and financial events on Islamic banking. The literature predicting the impact of political events on the stock market of Pakistan include $[18,23]$. However, they address selected events and are limited in nature. Few studies also predict relationships with financial events. Refs. [24-27] highlighted the effect of the GFC on stock market indices. However, none of these studies delve into the aftermath of the GFC in the Islamic banking sector. Moreover, the literature lacks data on the fluctuations in the exchange rate and on COVID-19. We must try to resolve the above-mentioned shortcomings, and in this way contribute to the literature. 


\section{Literature Review}

This section reviews previous studies related to this topic and methodology. Moreover, empirical studies on the impact of political, financial, and COVID-19-related events on Islamic banks' stock prices and volatilities are discussed. It is projected that the potential consequences of the coronavirus pandemic are much worse than any other worldwide disaster [2]. Several studies have been published on the effects of political or electionrelated events on stock prices. Most of them used US data and the patterns of that country's presidential elections. For instance, Refs. [28-33] favor the election cycle in the context of returns. Ref. [34] noted the effects of American and Canadian government changes on the Canadian stock market. Moreover, Ref. [35] supports the transnational effect of US elections on the stock market indexes of 18 countries. In 2000, Ref [36] found the effects of election outcomes on 33 countries' stock markets. Some exceptions also exist, but overall, the effects are mixed. Other studies have also shown that the return on stock is more evident under Republican governments [32,37] and there is not much evidence for the contrary. Ref. [30] claimed that returns do not vary much among Republican and Democrat governments. Ref. [29] also supported Huang's results.

The literature is scarce on the impacts on Islamic banking, especially in the context of the government system (democratic or autocratic). Most governments these days comprise coalitions. A government based on a coalition is not stable, and it may be replaced by a regime that was not elected. Questions arise as to whether these changes affect stock in the same way as government changes through by-elections. Evaluating political risk is challenging, although the events that generate political risk are easy to recognize [38-40]. Several terminologies are used to address political risk in the literature. Political risk, political instability, and political uncertainty are the most common terminologies. Unexpected changes in tax rules, election results, government policies, international or domestic conflicts, institutional instability, etc., all denote political risk [41]. We claim in this research that political risk evaluations must have the ability to predict returns.

Following [42], this study relies on a subjective assessment of the political risk posed to Pakistan's Islamic banks' returns. Different political measures have been used previously in the economic and financial literature, i.e., election uncertainty $[39,43,44]$, domestic conflict [45,46], social instability [47], corruption [48-50], political unrest [51-53], and institutional instability [54].

Political risk has been explored in several studies [40,42,55-58]. They used a form of political risk that comprises 12 indicators, including external conflicts, government stability, ethnic tensions, internal conflicts, socioeconomic conditions, law and order, military involvement in politics, investment profile, religious tensions, bureaucracy quality, corruption, and democratic accountability. Banks' assets are made volatile due to political risk through two channels. Capital cost is considered the first channel. Several studies argue that political risk affects the volatility of a firm's equity [30,55,59-63]. As political risk increases, the cost of capital is used as a discount factor in the firm valuation model. We claim that political instability affects firms' cash flows because it elevates the level of uncertainty surrounding the realization of projects' cash flows and their recovery.

In the financial literature, the COVID-19 pandemic's impacts are frequently compared with the GFC of over a decade ago, which is broadly address in research on interconnectedness, septicity, and the spillover effect [64-68]. Ref. [20] explored the impact of COVID-19 on stock and commodity markets' stability, and its effect on the food markets in Bangladesh [69]. However, the earlier Global Financial Crisis caused plenty of problems in the economies, whereas in the COVID-19 pandemic, one unique disaster is apparent. Government restrictions and actions were introduced as an instant response to the COVID-19 contagion because politicians had to act quickly to stop the spread. Ref. [70] identified the difference between COVID-19 and the GFC in that the pandemic crisis was the "Great Compression". 


\section{Methodology and Model Specifications}

This section describes the empirical analysis of volatility modeling and traces the impact of political and financial events on Islamic banks' returns and volatility series. The selected Islamic banks are listed on the KSE 100 index. The stock price series of the banks have an ARCH effect employed for volatility series, and we used GARCH modeling. Because the basic assumption of the OLS model is the homogeneity of variances, when the variance is dependent on time, we cannot use the OLS model. That is why for volatility series, we used GARCH modeling. The GARCH model is an extension of the ARCH model, which is used to avoid the lag length problem of the latter. We used the Impulse Indicator Saturation (IIS) technique to detect the impact of political and financial events on Islamic banks' returns and volatility series. This procedure is used by some researchers for the detection of structural breaks.

\subsection{Model Specifications}

The raw financial series mostly show a stochastic trend. For this reason, it is not possible to estimate valid results from the time series when there is a stochastic trend through GARCH modeling. On the other hand, when series have an ARCH effect, the heteroscedasticity can be reduced by taking the log. That is why this study makes returns series using the following formula:

$$
\mathrm{R}_{\mathrm{t}}=\log \left(\frac{\mathrm{l}_{\mathrm{t}}}{\mathrm{l}_{\mathrm{t}-1}}\right)
$$

$l_{t}$ The current price, i.e., the stock price at $t$ time and the $l_{t-1}$ lag price of the series.

\subsubsection{ARCH Model}

To model the time series when the variance changes with time, [71] introduced the ARCH model. The ARCH model simultaneously estimates two equations: the conditional mean equation, which evaluates the data-generating process of returns, commonly through the ARMA process, and the conditional variance equation, which estimates the datagenerating method of variance based on the squared lag value of the residual. The general forms of the ARCH model equations are written below:

Conditional mean

$$
\mathrm{R}_{\mathrm{t}}=\delta_{0}+\delta_{1} \mathrm{M}_{\mathrm{t}}+\varepsilon_{\mathrm{t}}
$$

where $\varepsilon_{\mathrm{t}}=\mathrm{z}_{\mathrm{t}} \sigma_{\mathrm{t}}, \mathrm{z}_{\mathrm{t}} \sim \mathrm{N}(0,1)$

Conditional variance

$$
\sigma_{\mathrm{t}}^{2}=\tau_{0}+\sum_{\mathrm{i}=1}^{\mathrm{q}} \tau_{\mathrm{i}} \varepsilon_{\mathrm{t}-\mathrm{i}}^{2}+\mathrm{v}_{\mathrm{t}}
$$

where $\mathrm{i}=1,2, \ldots, \mathrm{q}$.

$R_{t}$ is the presentation of the return series, while $\delta_{1}$ directs the parameter vector of the ARMA (p, q) process. The $\delta_{1} \mathrm{M}_{\mathrm{t}}$ the term is the general form of the ARMA $(\mathrm{p}, \mathrm{q})$ process. This process can be ARMA $(0,0)$ in some scenarios. There are some assumptions made by the ARCH model; the parameters of the conditional variance equation must come up with a positive sign. The ARCH model only captures a symmetric effect in the returns. $\varepsilon_{t}$ is the error term whereas the term $\varepsilon_{\mathrm{t}-\mathrm{i}}^{2}$ is known as the ARCH effect.

\subsubsection{GARCH Model}

The problem with the ARCH model is the long lag length of the ARCH process, which reduces the degree of freedom. To overcome this problem, Ref. [72] introduced a valuable extension of the ARCH model, which is known as the Generalized Autoregressive Conditional Heteroscedastic (GARCH) model. To tackle this problem, the lag value of the conditional variance equation was introduced in the conditional variance equation as an independent variable. Ref. [27] employed GARCH modeling to model the stock indices of Pakistani and foreign stock markets. 
The general forms of the equations of the GARCH $(p, q)$ model are given below:

Conditional mean

$$
\mathrm{R}_{\mathrm{t}}=\delta_{0}+\delta_{1} \mathrm{M}_{\mathrm{t}}+\varepsilon_{\mathrm{t}}
$$

where $\varepsilon_{\mathrm{t}}=\mathrm{z}_{\mathrm{t}} \sigma_{\mathrm{t}}, \mathrm{z}_{\mathrm{t}} \sim \mathrm{N}(0,1)$

Conditional variance

$$
\sigma_{t}^{2}=\tau_{0}+\sum_{i=1}^{q} \tau_{i} \varepsilon_{t-i}^{2}+\sum_{j=1}^{p} \theta_{j} \sigma_{t-j}^{2}+v_{t}
$$

$\mathrm{R}_{\mathrm{t}}$ is the presentation of the return series and $\delta_{1}$ directs the parameter vector of the ARMA (p, q) process. The $\delta_{1} \mathrm{M}_{\mathrm{t}}$ term is the general form of the ARMA (p, q) process. This process is ARMA $(0,0)$ in some scenarios. There are some assumptions made by the $\mathrm{ARCH}$ model; the parameters of the conditional variance equation must come up with a positive sign, while the ARCH model only captures a symmetric effect in the returns. The $\varepsilon_{\mathrm{t}}$ is the error term, $\varepsilon_{\mathrm{t}-\mathrm{i}}^{2}$ is the ARCH term and $\theta_{\mathrm{j}}$ is the parameter of the lag value of conditional variance.

\subsubsection{Impulse Indicator Saturation (IIS)}

The Impulse Indicator Saturation (IIS) process was devised by [73]. The purpose of this process is to detect the shift in the intercept, co-breaks, breaks and multiple breaks. This process is unrestricted and general, and that is why it is also known as an unrestricted model (GUM). The IIS procedure checks the break on each point of the data. A dummy variable is generated against each value in the data to capture the effects of events or breaks. There is a general rule in econometrics that the number of estimated parameters must be smaller than the number of observations. This procedure deals with this rule by introducing a specific number of dummy variables and runs regression; after that it runs the second regression with the next dummies, and so on. In this way, the regression analysis remains unviolated. The break could be significant on a different level of significance, and that is why we can set a specific level of significance according to our objective. We use the Impulse Indicator Saturation (IIS) technique to estimate the effects of political and financial events on the Islamic banks that are listed on the KSE 100 index.

The data from January 2007 to July 2020 are used, and the total number of observations is 2968 . We set the criteria to introduce 250 dummies in one regression, and then the IIS runs 12 regressions. The generalized form of regression is written as follows:

$$
R_{i t}=\pi_{0}+\pi_{1} R_{i t-1}+\sum_{t_{1}=1}^{250} \tau_{t} B_{i t}+\varepsilon_{i t}
$$

$$
\varepsilon_{i t} \sim \operatorname{IIN}\left(0, \sigma_{\mathrm{t}}^{2}\right) \mathrm{t}_{1}=1,2, \ldots, 250
$$

$$
\mathrm{R}_{\mathrm{it}}=\pi_{0}+\pi_{1} \mathrm{R}_{\mathrm{it}-1}+\sum_{\mathrm{t}_{1}=251}^{500} \tau_{\mathrm{t}_{2}} \mathrm{~B}_{\mathrm{it}}+\varepsilon_{\mathrm{it}}
$$

$$
\varepsilon_{\text {it }} \sim \operatorname{IIN}\left(0, \sigma_{\mathrm{t}}^{2}\right) \mathrm{t}_{2}=251,252, \ldots, 500
$$

$$
R_{i t}=\pi_{0}+\pi_{1} R_{i t-1}+\sum_{t_{12}=2501}^{2968} \tau_{t_{12}} B_{i t}+\varepsilon_{i t}
$$

$$
\varepsilon_{\text {it }} \sim \operatorname{IIN}\left(0, \sigma_{\mathrm{t}}^{2}\right) \mathrm{t}_{12}=2501, \ldots, 2968
$$

\subsection{Methodology}

Data visualization is employed to understand the nature and behavior of the return time series. The descriptive statistics explain the essential characteristics of the returns series of Islamic banks. A GARCH type model is used to model the volatility of Islamic 
banks' stock prices. In the end, the IIS procedure is adopted to check the impact of political and financial events on Islamic banks' returns and volatility series. For details of events, see Appendix A (Table A1).

\section{Results and Discussion}

\subsection{Data Visualization}

In this section, we visualize the series and their characteristics, which provides us with a basic understanding of the nature and behavior of the series.

Figure 1 shows that the stock price series of both banks are, overall, moving upward, or have an upward trend with some fluctuations.

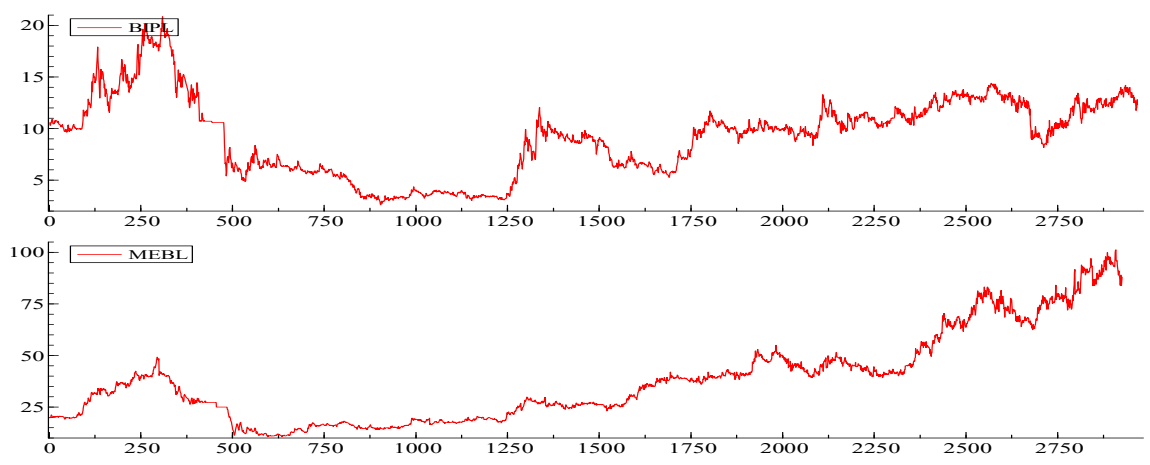

Figure 1. The raw series of BIPL and MEPL.

These fluctuations emerged due to some external and internal shocks, which made the series volatile.

Figure 2 displays the returns series of BIPL and MEPL banks. It shows the dispersion of return from the mean value, which is sometimes also known as volatility. There are some circles that explain the low volatility and high volatility clustering. The dashed-line circles show the high-volatility clustering, and plain-line circles indicate low-volatility clustering. These clustering points also suggest the presence of the ARCH effect.

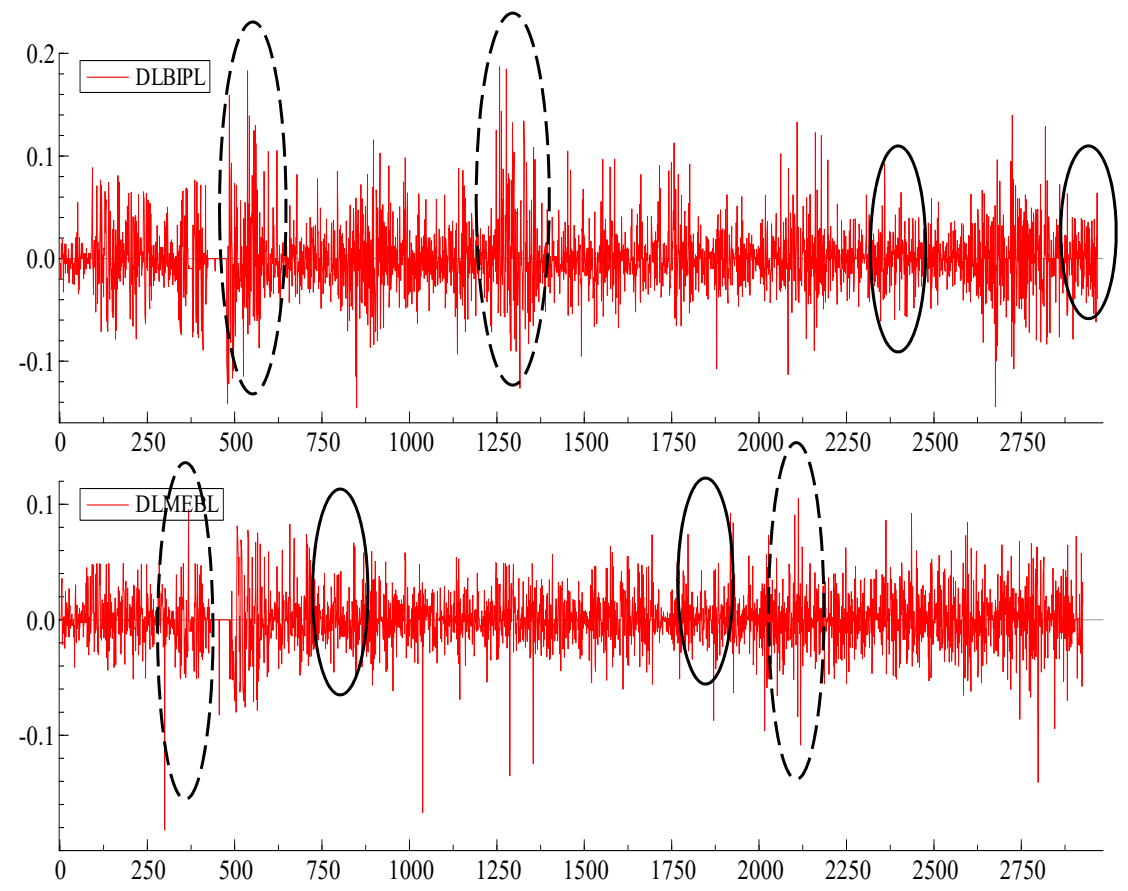

Figure 2. The returns series of BIPL and MEPL. 
Figure 3 shows the ACF and PACF of the return's series of BIPL banks. The ACF explains the autoregressive behavior of BIPL, which means the lag of effects for the current value, and PACF outlines the moving average, which highlights the lag variation effect. The red line shows the ACF, and blue indicates the PACF.

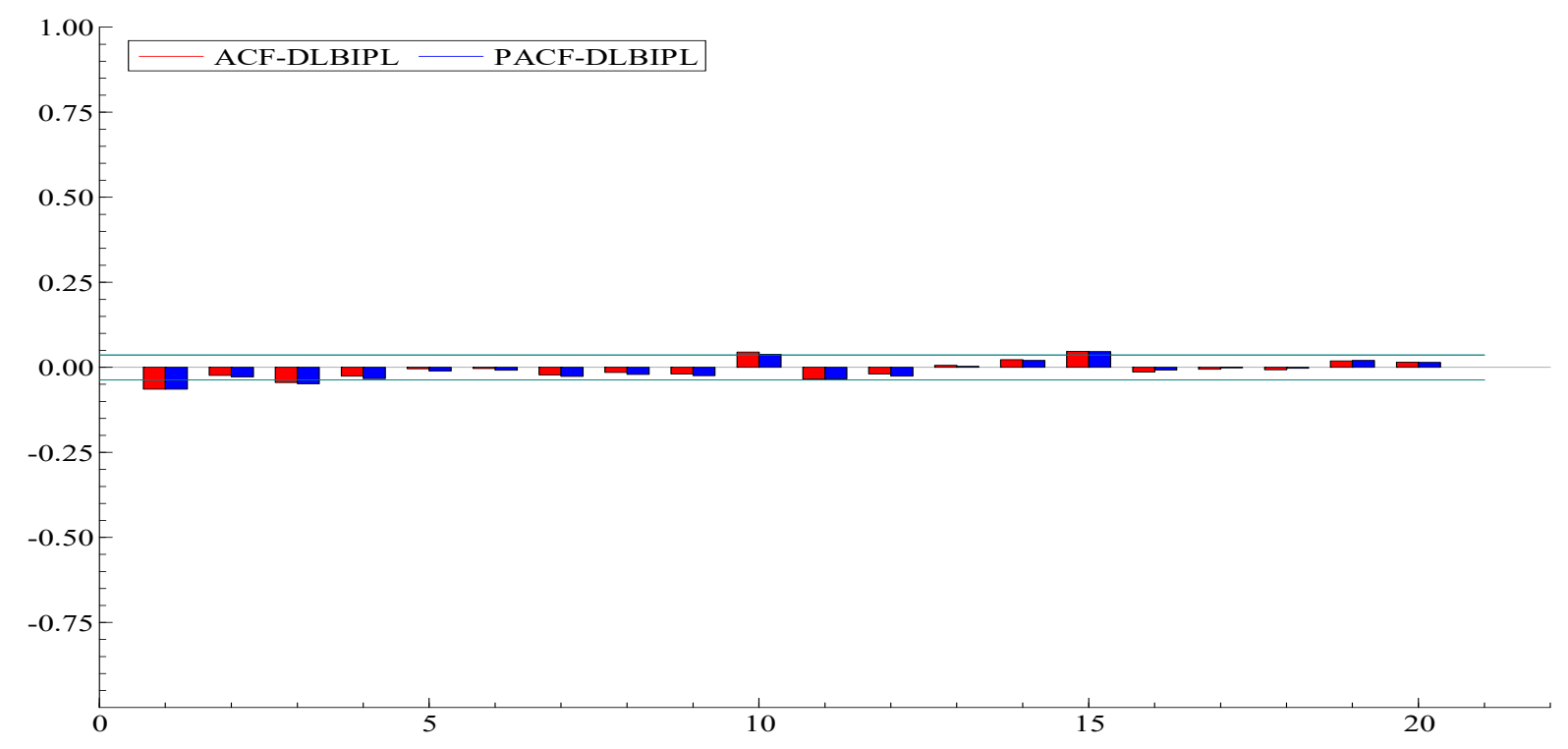

Figure 3. The ACF and PACF of BIPL.

The bar outside the lines is the significant lag value. The figure reveals that only the first three lags are outside the lines. For convenience, the figure is made solely for BIPL, but it can be made for other bank return series.

Figure 4 shows the distribution of the returns of Bank Islamic (BIPL), showing that the distribution has a large tail when compared to the normal distribution. In this figure, the red line shows the actual distribution of returns and the green line indicates the normal distribution. It means that the distribution is not symmetric. The peak of the distribution is also higher than the normal distribution, which means that the distribution is leptokurtic.

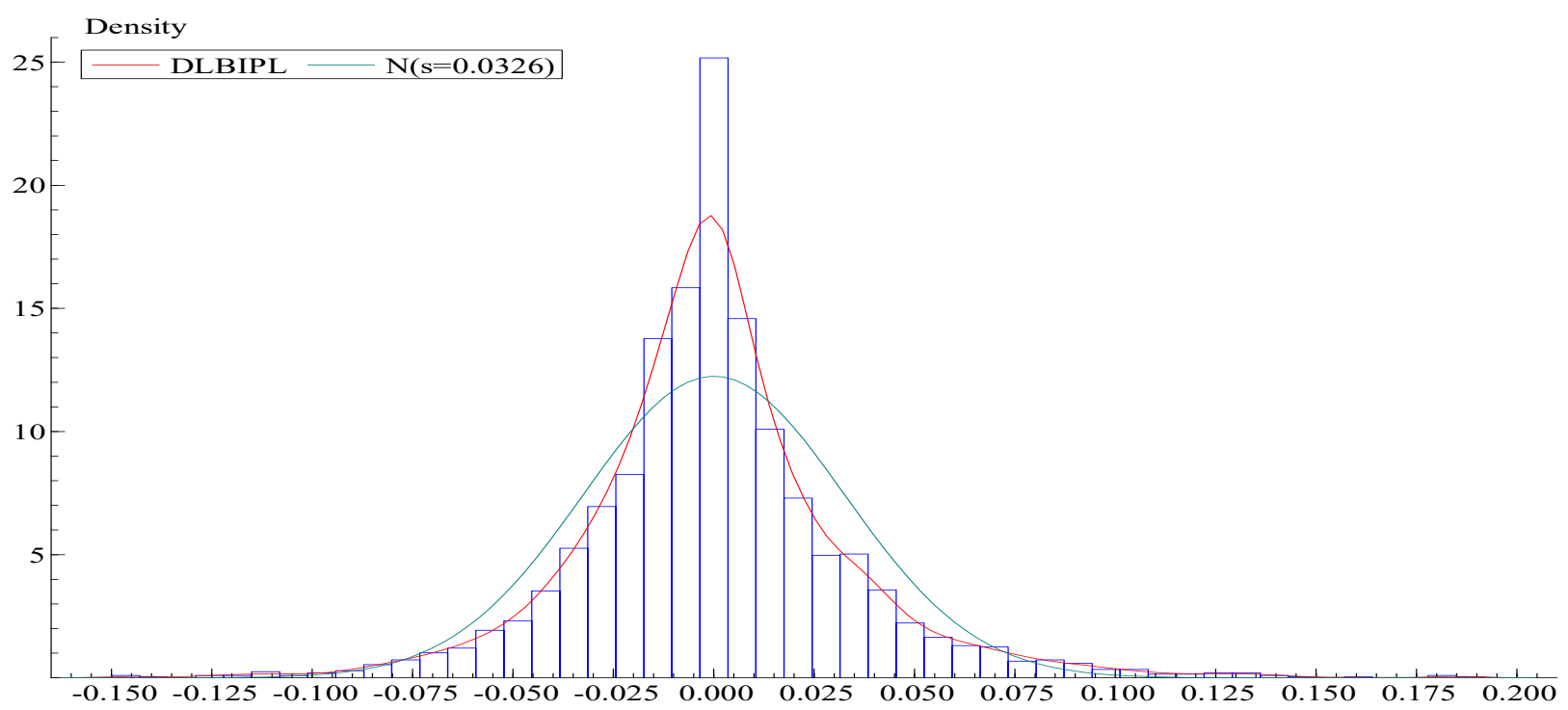

Figure 4. The distribution of the returns of BIPL. 


\subsection{Descriptive Statistics}

The descriptive statistics provide initial statistics on the nature and characteristics of the data series. The summary of statistics is given below in Table 1.

Table 1. The descriptive statistics of BIPL and MEBL.

\begin{tabular}{|c|c|c|c|c|c|c|c|c|c|}
\hline \multirow[b]{2}{*}{ Series } & \multicolumn{9}{|c|}{ Summary of Statistics } \\
\hline & Mean & Std. Error & Skewness & Jarque-Bera & $\begin{array}{c}\text { Excess } \\
\text { Kurtosis }\end{array}$ & Q Stat (5) & $\begin{array}{l}\text { Q2-Stat } \\
\text { (5) }\end{array}$ & $\begin{array}{c}\text { ARCH } \\
1-2\end{array}$ & KPSS \\
\hline BIPL & 0.00005 & 0.03257 & $\begin{array}{l}0.47269 \\
(0.0000)\end{array}$ & $1502.3(0.0021)$ & $\begin{array}{c}3.3812 \\
(0.0000)\end{array}$ & $\begin{array}{l}20.1270 \\
(0.0011)\end{array}$ & $\begin{array}{l}393.971 \\
(0.0000)\end{array}$ & $\begin{array}{c}63.815 \\
(0.0000)\end{array}$ & 0.11966 \\
\hline MEBL & 0.00051 & 0.02448 & $\begin{array}{l}-0.2617 \\
(0.0000)\end{array}$ & $1741.9(0.0000)$ & $\begin{array}{c}3.7441 \\
(0.0000)\end{array}$ & $\begin{array}{l}39.9162 \\
(0.0000)\end{array}$ & $\begin{array}{l}90.8753 \\
(0.0000)\end{array}$ & $\begin{array}{c}31.168 \\
(0.0000)\end{array}$ & 0.12908 \\
\hline
\end{tabular}

Null Hypotheses

KPSS H0: Return series is level stationary, asymptotic significant values 1\% (0.739), 5\% (0.463), 10\% (0.347). Q stat (return series): there is no serial autocorrelation. Q2-stat (square return series) H0: there is no serial autocorrelation. Jarque-Bera $\mathrm{H}_{0}$ : distribution of series is normal. LM-ARCH H0: there is no ARCH effect. Use the asymptotic significance values of t-stat $1 \%(0.01), 5 \%(0.05), 10 \%$ (0.1) and compare these critical values with $p$-values (Probability values). $p$-values are in the parenthesis".

Table 1 describes the results of the summarized statistics. The mean value indicates the average value of the series, which shows that on average the returns are close to zero. This means the returns series follows a mean reversion behavior. The standard deviation explains the deviation from the mean value, and the variation of both series from the mean is not too high. The skewness explains the symmetry of the distribution, and in both cases the skewness values are significant; this means both series are asymmetric, while the BIPL distribution is positively tailed and the distribution of MEBL is negatively skewed. The JB is the test of normality with a null hypothesis that the distribution is normal. The statistics of JB show that the distribution is not normal because it rejects the null hypothesis. The excess kurtosis indicates that the distribution does not have a normal peak; it is higher than the average level, and that is why it is leptokurtic. The $\mathrm{Q}$ stat explains that the returns have an autoregressive behavior.

In contrast, the $\mathrm{Q}$ square statistic reveals that the returns square, which is equal to the variance, also exhibits autoregressive behavior. The ARCH effect test explains that the returns series have an ARCH effect, and the KPSS test shows that both returns series are stationary.

\subsection{Volatility Modeling}

The objective of this study to check the impact of political and financial events on the returns and volatility of Islamic banks. So, to find the volatility series, we employ GARCH modeling. The volatility series are generated through the conditional variance equation - the results of GARCH modeling are given below in Tables 2 and 3. Table 2 explains the results of the GARCH model of BIPL. The first panel of Table 2 explains that the $\vartheta_{1}$ autoregressive parameter is significant. The $\varnothing_{1}$ is the parameter of the moving average, which is also significant. This means that the returns of BIPL follow the ARMA $(1,1)$ process. The second panel of Table 2 shows the results of the conditional variance equation of the GARCH model.

The ARCH term coefficient $\gamma_{1}$ is significant, meaning there is an ARCH that effects the conditional variance of BIPL. The coefficient of the GARCH term $\delta_{1}$ is also significant. This means that the conditional variance is also following the $\operatorname{GARCH}(1,1)$ specification. The Student- $t$ term is substantial, and this means it follows the $t$ distribution. The persistence of shock is close to 1, which shows that the ARCH and GARCH effects take a long time to decay. 
Table 2. The volatility modeling of return series of BIPL.

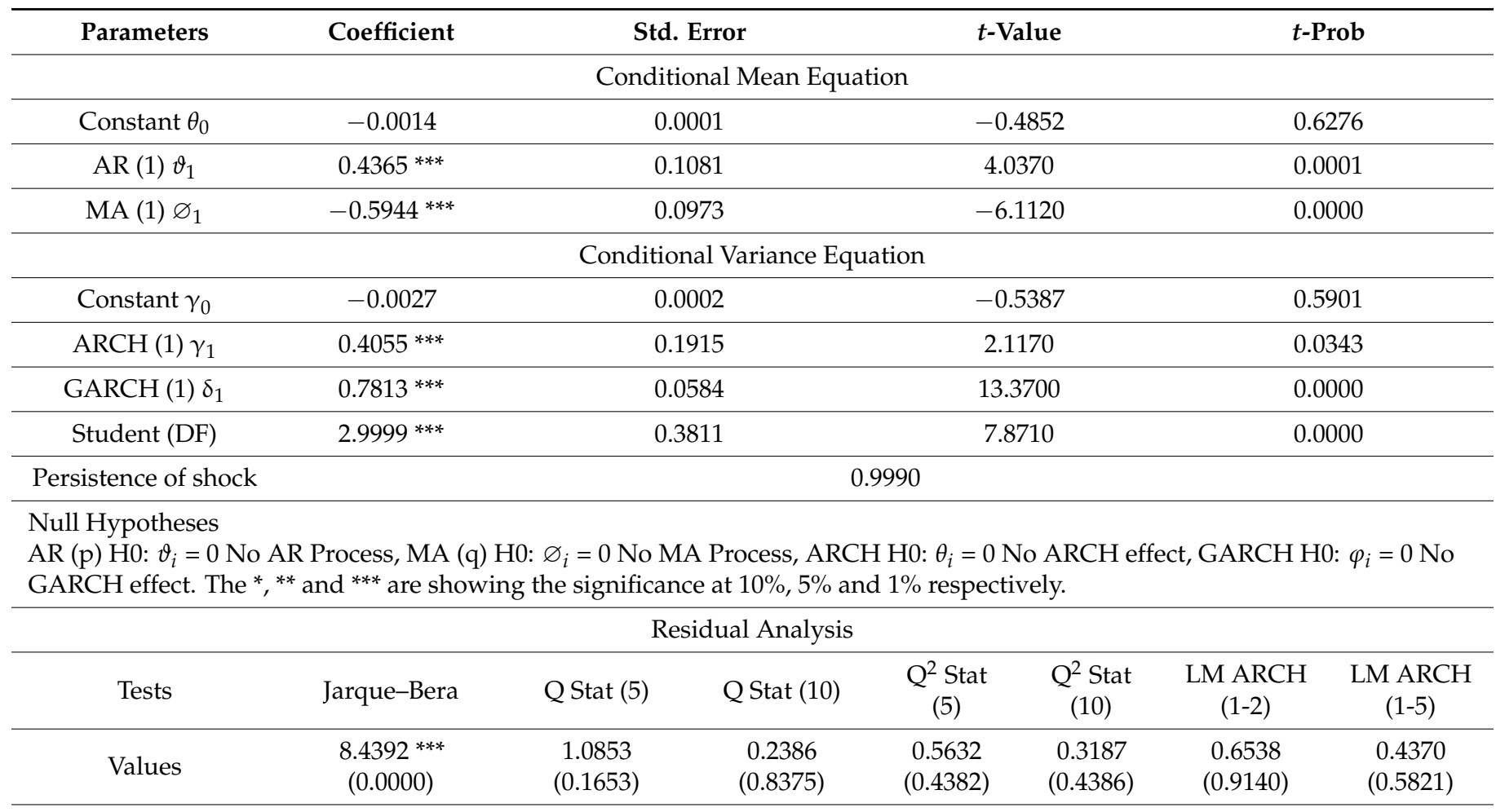

Null Hypotheses

In the $\mathrm{Q}$ stat (return series) there is no serial autocorrelation. $\mathrm{Q}^{2}$ stat (square return series) $\mathrm{H} 0$ : there is no serial autocorrelation. Jarque-Bera $\mathrm{H}_{0}$ : distribution of series is normal. LM-ARCH H $\mathrm{H}_{0}$ : there is no ARCH effect. $p$-values are in the parenthesis.

Table 3. The volatility modeling of return series of MEBL.

\begin{tabular}{|c|c|c|c|c|c|c|c|}
\hline Parameters & Coefficient & \multicolumn{2}{|c|}{ Std. Error } & \multicolumn{2}{|c|}{$t$-Value } & \multicolumn{2}{|c|}{$t$-Prob } \\
\hline \multicolumn{8}{|c|}{ Conditional Mean Equation } \\
\hline Constant $\theta_{0}$ & 0.0001 & \multicolumn{2}{|c|}{0.0003} & \multicolumn{2}{|c|}{0.3784} & \multicolumn{2}{|c|}{0.7052} \\
\hline $\operatorname{AR}(1) \vartheta_{1}$ & $0.0747^{* * *}$ & \multicolumn{2}{|c|}{0.0767} & \multicolumn{2}{|c|}{0.9744} & \multicolumn{2}{|c|}{0.0300} \\
\hline MA (1) $\varnothing_{1}$ & $-0.2789 * * *$ & \multicolumn{2}{|c|}{0.0731} & \multicolumn{2}{|c|}{-3.8140} & \multicolumn{2}{|c|}{0.0001} \\
\hline \multicolumn{8}{|c|}{ Conditional Variance Equation } \\
\hline Constant $\gamma_{0}$ & $0.8525^{* * *}$ & \multicolumn{2}{|c|}{0.2732} & \multicolumn{2}{|c|}{3.1200} & \multicolumn{2}{|c|}{0.0018} \\
\hline $\mathrm{ARCH}(1) \gamma_{1}$ & $0.3319^{* * *}$ & \multicolumn{2}{|c|}{0.0605} & \multicolumn{2}{|c|}{5.4820} & \multicolumn{2}{|c|}{0.0000} \\
\hline GARCH $(1) \delta_{1}$ & $0.5954^{* * *}$ & \multicolumn{2}{|c|}{0.0760} & \multicolumn{2}{|c|}{7.8380} & \multicolumn{2}{|c|}{0.0000} \\
\hline Student (DF) & $4.2501^{* * *}$ & \multicolumn{2}{|c|}{0.4087} & \multicolumn{2}{|c|}{10.4000} & \multicolumn{2}{|c|}{0.0000} \\
\hline Persistence of shock & \multicolumn{7}{|c|}{0.92725} \\
\hline \multicolumn{8}{|c|}{$\begin{array}{l}\text { Null Hypotheses } \\
\text { AR (p) H0: } \vartheta_{i}=0 \text { No AR Process, MA (q) H0: } \varnothing_{i}=0 \text { No MA Process, ARCH H0: } \theta_{i}=0 \text { No ARCH effect, GARCH H0: } \varphi_{i}=0 \text { No } \\
\text { GARCH effect. The }{ }^{* * *} \text { and }{ }^{* * *} \text { show significance at } 10 \%, 5 \% \text { and } 1 \% \text {, respectively. }\end{array}$} \\
\hline \multicolumn{8}{|c|}{ Residual Analysis } \\
\hline Tests & Jarque-Bera & Q Stat (5) & Q Stat (10) & $\mathrm{Q}^{2}$ Stat (5) & $\mathrm{Q}^{2}$ Stat $(10)$ & $\begin{array}{c}\text { LM ARCH } \\
(1-2)\end{array}$ & $\begin{array}{c}\text { LM ARCH } \\
(1-5) \\
\end{array}$ \\
\hline Values & $\begin{array}{c}19.7562 * * * \\
(0.0000)\end{array}$ & $\begin{array}{c}1.6892 \\
(0.26982)\end{array}$ & $\begin{array}{c}0.9874 \\
(0.2037)\end{array}$ & $\begin{array}{c}0.9851 \\
(0.7822)\end{array}$ & $\begin{array}{c}0.8371 \\
(0.7239)\end{array}$ & $\begin{array}{c}0.7312 \\
(0.2464)\end{array}$ & $\begin{array}{c}0.8748 \\
(0.8371)\end{array}$ \\
\hline
\end{tabular}

Null Hypotheses

In the $\mathrm{Q}$ stat (return series) there is no serial autocorrelation. $\mathrm{Q}^{2}$ stat (square return series) H0: there is no serial autocorrelation. Jarque-Bera $\mathrm{H}_{0}$ : distribution of series is normal. $\mathrm{LM}-\mathrm{ARCH} \mathrm{H} \mathrm{H}_{0}$ : there is no ARCH effect. $p$-values are in the parentheses. 
The third panel of Table 2 describes the results of the residual analysis, which validates the results of the regression. The Jarque-Bera (JB) is the test of normality, with a null hypothesis that the distribution is normal. The statistics of JB show that the distribution is not normal because it rejects the null hypothesis. The normality of the residual is not necessary for the validation of results. The $Q$ stat explains that the residuals have an autoregressive behavior. In contrast, the $\mathrm{Q}$ square stat shows that the square of the residuals, which is equal to the variance, also has a autoregressive behavior. The statistics of the test show that they are insignificant, which means that there is no more autocorrelation and heteroscedasticity. The ARCH test explains that the residuals have no ARCH effect.

Table 3 describes the results of the volatility modeling of MEBL. The first panel in this table shows that the $\vartheta_{1}$ autoregressive parameter is significant in the conditional mean equation. The $\varnothing_{1}$ is the parameter of the moving average, and it is also significant. This means that the returns of MEBL follow the ARMA $(1,1)$ process. The second panel of Table 2 displays the results of the conditional variance equation of the volatility modelling of MEBL. The ARCH term coefficient $\gamma_{1}$ is statistically significant, which shows that there is an ARCH effect that affects the conditional variance of MEBL. The coefficient of the GARCH term $\delta_{1}$ emerges as significant. This means that the conditional variance follows GARCH $(1,1)$ specification. The Student-t term is significant, which means that it follows the $t$ distribution. The persistence of shock is close to 1, confirming that the ARCH and GARCH effects take a long time to decay.

\subsection{The Impact of Political and Financial Events on BIPL and MEBL Returns and Volatility Series}

The Impulse Indicator Saturation procedure is used to check the significance of these COVID-19 pandemic-related political and financial events for the returns and volatility of BIPL and MEBL. The major 24 events have been selected, and the results of their impact on return series are given below in Table 4 .

The results documented in Table 4 show that all political and financial events affect the performance of BIPL and MEBL. The results reveal the significant impact of all political and financial events on the returns of BIPL and MEBL, except the ban on TV channels going to air on 14 November 2007, and the PGOp of 14 November 2007 and also on the 10 June 2010. Some events had only a minor impact on the returns of BIPL and MEBL. These events are not significant at the $5 \%$ level, but they are significant at $10 \%$; for example, the Osama Bin Laden Operation in Abbottabad and the civil disobedience campaign by Imran Khan on 2 May 2011 and 19 August 2014. While all three events during the unavoidable COVID-19 pandemic were highly significant, this means they had a momentous effect on the volatility and returns of Islamic banks. Table 5 lists the results of volatility series.

The results in Table 5 lead to the conclusion that all the political and financial events affected the performance of BIPL and MEBL. There was a significant impact of all the political and financial events on the volatility of BIPL and MEBL, except the ban on TV channels going to air on 14 November 2007 and the PGOp of 10 June 2010. There are some events that weakly impacted the volatility of BIPL and MEBL, and these were not significant at the 5\% level, yet they were at the 10\% level: the Osama Bin Laden Operation in Abbottabad, the civil disobedience campaign by Imran Khan, and PTI winning the general election on 2 May 2011, 19 August 2014 and 26 July 2018. The overall results indicate that the political and financial events affected the returns and volatilities of Islamic banks listed on the KSE 100. There are only two political events that did not shape the returns and volatility: firstly, the ban on TV channels going to air and the PGOp of 14 November 2007 and 10 June 2010, respectively. All three events, occurring due to COVID-19, were highly significant and had a huge impact on the returns and volatility series. 
Table 4. The impact on returns of BIPL and MEBL.

\begin{tabular}{|c|c|c|c|c|}
\hline Date & Category & Detail & BIPL (F-Stat) & MEBL (F-Stat) \\
\hline 14 November 2007 & Internal Affair & $\begin{array}{c}\text { Ban on TV channels going to } \\
\text { air }\end{array}$ & $1.8742(0.2835)$ & $0.4991(0.3759)$ \\
\hline 19 February 2008 & Elections & PPP won with a $1 / 3$ majority & $11.7542 * * *(0.0007)$ & $16.9443^{* * *}(0.0001)$ \\
\hline 15 May 2008 & Internal Affair & Strike for Justice Movement & $82.7620 * * *(0.0043)$ & $72.7621^{* * *}(0.0092)$ \\
\hline 7 September 2008 & Financial crisis & Global Financial Crisis & $57.8313^{* * *}(0.0000)$ & $9.7822 * * *(0.0000)$ \\
\hline 11 March 09 & Internal Affair & Long March/Riots & $34.8653 * * *(0.0000)$ & $23.3945^{* * *}(0.0000)$ \\
\hline 10 June 2010 & Internal Affairs & $\begin{array}{l}\text { Punjab Government Opposed } \\
\text { Rah e Najat Operation (PGOp) }\end{array}$ & $0.7218(0.4968)$ & $2.1362(0.3949)$ \\
\hline 2 May 2011 & Foreign Affairs & $\begin{array}{l}\text { Osama Bin Laden operation in } \\
\text { Abbottabad }\end{array}$ & $46.8434 *(0.0748)$ & $39.9853 *(0.0517)$ \\
\hline 28 October 2011 & $\begin{array}{l}\text { Long March/Political } \\
\text { Gathering }\end{array}$ & PML-N & $76.7522 * * *(0.0000)$ & $85.7642^{* * *}(0.0000)$ \\
\hline 31 October 2011 & $\begin{array}{l}\text { Long March/Political } \\
\text { Gathering }\end{array}$ & PTI & $21.7842 * * *(0.0000)$ & $48.7638^{* * *}(0.0000)$ \\
\hline 18 June 2012 & Internal Affairs & $\begin{array}{l}\text { SC dismissed Yousaf Raza } \\
\text { Gillani }\end{array}$ & $87.9472 * * *(0.0000)$ & $34.4074^{* * *}(0.0000)$ \\
\hline 15 January 2013 & $\begin{array}{l}\text { Long March/Political } \\
\text { Gathering }\end{array}$ & $\begin{array}{l}\text { Tahir ul Qadri sit-in in } \\
\text { Islamabad resulted from the } \\
\text { long march }\end{array}$ & $62.7492 * * *(0.0000)$ & $72.7842^{* * *}(0.0000)$ \\
\hline 13 May 2013 & Elections & PMLN won & $65.7462 * * *(0.0000)$ & $23.4982^{* * *}(0.0000)$ \\
\hline 5 June 2013 & Internal Affair & NS the PM of Pakistan & $3.8364(0.2621)$ & $3.7821(0.4580)$ \\
\hline 15 August 2014 & $\begin{array}{l}\text { Long March/Political } \\
\text { Gathering }\end{array}$ & PAT and PTI & $49.4952 * * *(0.0000)$ & $63.9848^{* * *}(0.0000)$ \\
\hline 19 August 2014 & Internal Affairs & $\begin{array}{l}\text { Civil disobdience encouraged } \\
\text { by Imran khan }\end{array}$ & $4.4023 *(0.0654)$ & $3.6482 *(0.0721)$ \\
\hline 20 February 2018 & Internal Affairs & SC dismissed Nawaz Sharif & $47.8031^{* * *}(0.0000)$ & $24.7492^{* * *}(0.0000)$ \\
\hline 13 July 2018 & Internal Affairs & $\begin{array}{c}\text { Mariam Nawaz and Nawaz } \\
\text { Sharif arrested }\end{array}$ & $12.2693 * * *(0.0000)$ & $23.7592 * * *(0.0000)$ \\
\hline 25 July 2018 & Internal Affairs & 2018 general election & $19.9824^{* * *}(0.0000)$ & $54.8132 * * *(0.0000)$ \\
\hline 26 July 2018 & Internal Affairs & PTI won & $4.4369 *(0.0729)$ & $5.8426 *(0.0821)$ \\
\hline 9 October 2018 & Exchange rate & Increased 122.44 to 132.58 & $43.4958 * * *(0.0054)$ & $62.8642^{* * *}(0.0049)$ \\
\hline 30 November 2018 & Exchange rate & Increased 132 to 136.58 & $37.8419 * *(0.0159)$ & $26.9352 * *(0.0421)$ \\
\hline 19 March 2020 & First outbreak of COVID-19 & $\begin{array}{l}\text { The first outbreak in Pakistan } \\
\text { of COVID-19 between } 11 \text { and } \\
19 \text { March }\end{array}$ & $67.2511^{* * *}(0.0000)$ & $35.9473^{* * *}(0.0000)$ \\
\hline 23 March 2020 & $\begin{array}{l}\text { First lockdown in Karachi } \\
\text { due to COVID-19 }\end{array}$ & $\begin{array}{l}\text { First lockdown in Karachi and } \\
\text { also Pakistan stock market } \\
\text { shut down due to COVID-19 }\end{array}$ & $37.2943^{* * *}(0.0000)$ & $49.4822^{* * *}(0.0000)$ \\
\hline 31 May 2020 & $\begin{array}{l}\text { Nationwide lock down due } \\
\text { to COVID-19 }\end{array}$ & $\begin{array}{l}\text { Nationwide lockdown in } \\
\text { Pakistan due to COVID-19 }\end{array}$ & $19.3831 * * *(0.0000)$ & $28.3612^{* * *}(0.0000)$ \\
\hline
\end{tabular}


Table 5. The impact on volatility of BIPL and MEBL.

\begin{tabular}{|c|c|c|c|c|}
\hline Date & Category & Detail & BIPL (F-Stat) & MEBL (F-Stat) \\
\hline 14 November 2007 & Internal Affairs & $\begin{array}{c}\text { Ban on TV channels going } \\
\text { to air }\end{array}$ & $2.8329(0.6392)$ & $0.3791(0.6920)$ \\
\hline 19 February 2008 & Elections & $\begin{array}{l}\text { PPP won with a } 1 / 3 \\
\text { majority }\end{array}$ & $14.4297^{* * *}(0.0000)$ & $27.9312^{* * *}(0.0000)$ \\
\hline 15 May 2008 & Internal Affairs & $\begin{array}{l}\text { Strike for Justice } \\
\text { Movement }\end{array}$ & $63.4783^{* * *}(0.0004)$ & $49.3849^{* * *}(0.0018)$ \\
\hline 7 September 2008 & Financial crisis & Global Financial Crisis & $57.6492 * * *(0.0000)$ & $56.3821^{* * *}(0.0000)$ \\
\hline 11 Mar 2009 & Internal Affairs & Long March/Riots & 49.3871 *** $(0.0000)$ & $37.3923 * * *(0.0000)$ \\
\hline 10 June 2010 & Internal Affairs & $\begin{array}{l}\text { Punjab Government } \\
\text { Opposed Rah e Najat } \\
\text { Operation (PGOp) }\end{array}$ & $0.3293(0.1522)$ & $1.3739(0.3949)$ \\
\hline 2 May 2011 & Foreign Affairs & $\begin{array}{c}\text { Osama Bin Laden } \\
\text { operation in Abbottabad }\end{array}$ & $5.3901 *(0.0561)$ & $9.6948 *(0.0849)$ \\
\hline 28 October 2011 & $\begin{array}{l}\text { Long March/Political } \\
\text { Gathering }\end{array}$ & PML-N & $62.7823 * * *(0.0000)$ & $38.3981^{* * *}(0.0000)$ \\
\hline 31 October 2011 & $\begin{array}{l}\text { Long March/Political } \\
\text { Gathering }\end{array}$ & PTI & $32.4629 * * *(0.0000)$ & $24.4821^{* * *}(0.0000)$ \\
\hline 18 June 2012 & Internal Affairs & $\begin{array}{l}\text { SC dismissed Yousaf Raza } \\
\text { Gillani }\end{array}$ & $21.3031^{* * *}(0.0000)$ & $35.3309^{* * *}(0.0000)$ \\
\hline 15 January 2013 & $\begin{array}{l}\text { Long March/Political } \\
\text { Gathering }\end{array}$ & $\begin{array}{l}\text { Tahir ul Qadri sit-in in } \\
\text { Islamabad resulted from } \\
\text { the long march }\end{array}$ & $42.3916(0.0000)$ & $19.1093(0.0000)$ \\
\hline 13 May 2013 & Elections & PMLN won & $65.7462 * * *(0.0000)$ & $23.4982^{* * *}(0.0000)$ \\
\hline 5 June 2013 & Internal Affairs & NS the PM of Pakistan & $5.8749 *(0.0872)$ & $4.3782 *(0.0749)$ \\
\hline 15 August 2014 & $\begin{array}{l}\text { Long March/Political } \\
\text { Gathering }\end{array}$ & PAT and PTI & $83.3879 * * *(0.0000)$ & $92.4829^{* * *}(0.0000)$ \\
\hline 19 August 2014 & Internal Affairs & $\begin{array}{l}\text { Civil disobdience } \\
\text { encouraged by Imran Khan }\end{array}$ & $8.3783 *(0.0629)$ & $3.3982 *(0.0932)$ \\
\hline 20 February 2018 & Internal Affairs & SC dismissed Nawaz Sharif & $72.8992 * * *(0.0000)$ & $31.4872^{* * *}(0.0000)$ \\
\hline 13 July 2018 & Internal Affairs & $\begin{array}{l}\text { Mariam Nawaz and } \\
\text { Nawaz Sharif arrested }\end{array}$ & $46.7322 * * *(0.0000)$ & $64.4762^{* * *}(0.0000)$ \\
\hline 25 July 2018 & Internal Affairs & 2018 general eclection & $46.4581^{* * *}(0.0002)$ & $32.4892^{* * *}(0.0000)$ \\
\hline 26 July 2018 & Internal Affairs & PTI won & $6.3893 *(0.0519)$ & $8.4873 *(0.0621)$ \\
\hline 9 October 2018 & Exchange rate & Increased 122.44 to 132.58 & $42.4934^{* * *}(0.0000)$ & $37.4213^{* * *}(0.0000)$ \\
\hline 30 November 2018 & Exchange rate & Increased 132 to 136.58 & $42.3091^{* * *}(0.0047)$ & $34.8423 * *(0.0124)$ \\
\hline 19 March 2020 & $\begin{array}{l}\text { First outbreak of } \\
\text { COVID-19 }\end{array}$ & $\begin{array}{l}\text { The first outbreak in } \\
\text { Pakistan of COVID-19 } \\
\text { between } 11 \text { and } 19 \text { March }\end{array}$ & $27.3462 * * *(0.0000)$ & $64.2190^{* * *}(0.0000)$ \\
\hline 23 March 2020 & $\begin{array}{l}\text { First lockdown in } \\
\text { Karachi due to } \\
\text { COVID-19 }\end{array}$ & $\begin{array}{l}\text { First lockdown in Karachi } \\
\text { and the Pakistan stock } \\
\text { market also shut down due } \\
\text { to COVID-19 }\end{array}$ & $31.4924^{* * *}(0.0000)$ & $19.4822^{* * *}(0.0000)$ \\
\hline 31 May 2020 & $\begin{array}{l}\text { Nationwide lockdown } \\
\text { due to COVID-19 }\end{array}$ & $\begin{array}{l}\text { Nationwide lockdown in } \\
\text { Pakistan due to COVID-19 }\end{array}$ & $29.3822 * * *(0.0047)$ & $64.3712^{* * *}(0.0023)$ \\
\hline
\end{tabular}




\section{Conclusions and Policy Discussion}

The stock markets play a critical role in any economy. The stability of an economy is also based on the performance of the stock market. The Islamic banking sector in the stock market of Pakistan has revealed its importance over time. However, when any shock hits the stock market, its effect is also seen in the stock prices of all the sectors listed on the Pakistan stock exchange. We selected some major political and financial events and explored their impact on the performance of Islamic banks listed on the KSE 100 index.

The returns series and volatility series of BIPL and MEBL were impacted by 19 out of 21 events. The returns series and volatility series of BIPL and MEBL were impacted by all internal and external financial events. The political events that did not affect the return and volatility of Islamic banks were the ban on TV channels going to air and the PGOp on the 14 November 2007 and 10 June 2010, respectively. The financial events that did not affect the returns and volatility of Islamic banks are the ban on TV channels going to air and the PGOp on 14 November 2007 and 10 June 2010, respectively. Some political events weakly affected the returns and volatility of Islamic banks: the Osama Bin Laden Operation in Abbottabad and PTI winning the elections on 2 May 2011 and 26 July 2018, respectively. All three events occurring due to COVID-19 turned out to be highly significant. They had a huge impact on returns and volatility series. The conclusion can be drawn that COVID-19 and political and financial events affected the performance of the Islamic banking sector in all but two cases.

The results could provide direction for the Central Bank of Pakistan, regarding how Islamic banks should develop and implement policy when political and financial events occur. The Islamic banks can use the results of this study to make policies regarding stock market shares. Finally, the Islamic banks can use these results for future policy-making when such political and financial events emerge.

Author Contributions: Data curation, G.G.; formal analysis, A.A. and G.G.; investigation, G.G. and M.I.B.; methodology, G.G. and M.I.B.; resources, A.A.; software, G.G.; supervision, M.I.B. All authors have read and agreed to the published version of the manuscript.

Funding: This research received no external funding.

Institutional Review Board Statement: Not applicable.

Informed Consent Statement: All authors agreed.

Data Availability Statement: The date is given on 1st column or https:/ /www.dawn.com/news/29 0178/ppp-pml-n-in-sight-of-magical-number.

Conflicts of Interest: The authors declare no conflict of interest.

\section{Appendix A}

Summaries of events are given below in Table A1.

Table A1. Events and their sources.

\begin{tabular}{|c|c|c|c|}
\hline Dates & Category & Detail & Source \\
\hline 14 November 2007 & Internal Affairs & Ban on TV channels & $\begin{array}{l}\text { https:// www.dawn.com/news/275656/tv-channels- } \\
\text { abiding-by-code-to-go-on-air (accessed on } 9 \text { April 2018) }\end{array}$ \\
\hline 19 February 2008 & Elections & $\begin{array}{l}\text { Pakistan People's Party won } \\
\text { with a } 1 / 3 \text { majority }\end{array}$ & $\begin{array}{l}\text { https:/ / www.dawn.com/news/290178/ppp-pml-n-in- } \\
\text { sight-of-magical-number (accessed on } 9 \text { April 2018) }\end{array}$ \\
\hline 15 May 2008 & Internal Affairs & $\begin{array}{l}\text { Strike for Chief Justice } \\
\text { Movement }\end{array}$ & $\begin{array}{l}\text { https://www.hrw.org/report/2007/12/18/destroying- } \\
\text { legality/pakistans-crackdown-lawyers-and-judges } \\
\text { (accessed on } 9 \text { April 2018) }\end{array}$ \\
\hline 7 September 2008 & Financial crisis & Global Financial Crisis & $\begin{array}{c}\text { https:/ / www.ipripak.org/wp-content/uploads/2014/0 } \\
\text { 1/art5usmw10.pdf (accessed on } 9 \text { April 2018) }\end{array}$ \\
\hline 11 March 2009 & Internal Affairs & Long March/Riots & $\begin{array}{l}\text { https: / / www.dawn.com/news/630027/ fallout-from-the- } \\
\text { 2009-long-march (accessed on } 9 \text { April 2018) }\end{array}$ \\
\hline
\end{tabular}


Table A1. Cont.

\begin{tabular}{|c|c|c|c|}
\hline Dates & Category & Detail & Source \\
\hline 10 June 2010 & Internal Affairs & $\begin{array}{l}\text { Punjab Government Opposed } \\
\text { Rah-e-Najaat Operation }\end{array}$ & $\begin{array}{l}\text { https:/ / defence.pk/pdf/threads / operation-rah-e-nijat- } \\
\text { south-waziristan.36574/page-59 (accessed on } 9 \text { April 2018) }\end{array}$ \\
\hline 2 May 2011 & Foreign Affairs & $\begin{array}{l}\text { Osama Bin Laden operation } \\
\text { in Abbottabad }\end{array}$ & $\begin{array}{c}\text { https://tribune.com.pk/story/160560/the-operation- } \\
\text { what-exactly-happened-in-abbottabad } \\
\text { (accessed on } 9 \text { April 2018) }\end{array}$ \\
\hline 28 October 2011 & $\begin{array}{l}\text { Long March/Political } \\
\text { Gathering }\end{array}$ & $\begin{array}{l}\text { Political gathering by } \\
\text { Pakistan Muslim League } \\
\text { Nawaz (PML-N) }\end{array}$ & $\begin{array}{c}\text { https:// www.pakistantoday.com.pk/2011/12/14/ppp- } \\
\text { grills-pml-n-over-maryam-nawaz\%E2\%80\%99s-political- } \\
\text { launch/ (accessed on } 9 \text { April 2018) }\end{array}$ \\
\hline 31 October 2011 & Political Gathering & $\begin{array}{l}\text { Political gathering by } \\
\text { Pakistan Tehreek-e-Insaf }\end{array}$ & $\begin{array}{l}\text { https:/ / tribune.com.pk/story / } 285058 \text { /pti-rally-in- } \\
\text { lahore-live-updates (accessed on } 9 \text { April 2018) }\end{array}$ \\
\hline 18 June 2012 & Internal Affairs & $\begin{array}{l}\text { Supreme Court dismissed } \\
\text { Yousef Raza Gillani }\end{array}$ & $\begin{array}{l}\text { https://www.theguardian.com/world/2012/jun/19 } \\
\text { /pakistan-prime-minister-yousuf-gilani-disqualified } \\
\text { (accessed on } 9 \text { April 2018) }\end{array}$ \\
\hline 15 January 2013 & $\begin{array}{l}\text { Long March/Political } \\
\text { Gathering }\end{array}$ & $\begin{array}{l}\text { Tahir-ul-Qadri protest in } \\
\text { Islamabad resulting from the } \\
\text { long march }\end{array}$ & $\begin{array}{c}\text { https://www.dawn.com/news/779452/talks-between- } \\
\text { govt-qadri-concluded-successfully } \\
\text { (accessed on 9 April 2018) }\end{array}$ \\
\hline 13 May 2013 & Elections & New Government by PML-N & $\begin{array}{c}\text { https: / /www.aljazeera.com/news/2013/5/13/sharif- } \\
\text { assembling-new-pakistan-government } \\
\text { (accessed on } 9 \text { April 2018) }\end{array}$ \\
\hline 5 June 2013 & Internal Affairs & $\begin{array}{l}\text { Nawaz Sharif took oath as the } \\
\text { Prime Minister of Pakistan }\end{array}$ & $\begin{array}{l}\text { https://www.bbc.com/news/world-asia-22767734 } \\
\text { (accessed on } 9 \text { April 2018) }\end{array}$ \\
\hline 15 August 2014 & $\begin{array}{l}\text { Long March/Political } \\
\text { Gathering }\end{array}$ & $\begin{array}{l}\text { Protest by Pakistan Awami } \\
\text { Tehreek (PAT) and PTI }\end{array}$ & $\begin{array}{l}\text { https: / / www.dawn.com/news/1125710 } \\
\text { (accessed on } 9 \text { April 2018) }\end{array}$ \\
\hline 19 August 2014 & Internal Affairs & $\begin{array}{l}\text { Civil disobedience by Imran } \\
\text { Khan }\end{array}$ & $\begin{array}{l}\text { https:/ / www.dawn.com/news/1133132 } \\
\text { (accessed on } 9 \text { April 2018) }\end{array}$ \\
\hline 20 February 2018 & Internal Affairs & $\begin{array}{l}\text { Supreme Court dismissed } \\
\text { Nawaz Sharif on corruption } \\
\text { charges }\end{array}$ & $\begin{array}{l}\text { https: / / www.cnbc.com/2018/04/13/pakistan- } \\
\text { disqualifies-former-prime-minister-nawaz-sharif-from- } \\
\text { holding-office.html (accessed on } 9 \text { April 2018) }\end{array}$ \\
\hline 13 July 2018 & Internal Affairs & $\begin{array}{l}\text { Mariam Nawaz and Nawaz } \\
\text { Sharif arrested }\end{array}$ & $\begin{aligned} \text { https: / / www.dawn.com/news / } 1419756 \\
\text { (accessed on } 9 \text { April 2018) }\end{aligned}$ \\
\hline 25 July 2018 & Internal Affairs & 2018 general election & $\begin{array}{l}\text { https: / / www.ecp.gov.pk / frmPartyDetails.aspx?EleId=1\& } \\
\text { EID=10070\&constType=NA\&Election=General\%20 } \\
\text { Election\%2025\%20Jul\%202018 (accessed on } 9 \text { April 2018) }\end{array}$ \\
\hline 26 July 2018 & Internal Affairs & PTI made a new government & $\begin{array}{l}\text { https: / /www.dawn.com/news /1423370 } \\
\text { (accessed on } 9 \text { April 2018) }\end{array}$ \\
\hline 9 October 2018 & Exchange rate & $\begin{array}{l}\text { Depreciation of Pakistani } \\
\text { Rupee against US Dollar from } \\
122.44 \text { to } 132.58\end{array}$ & $\begin{array}{l}\text { https: / / tradingeconomics.com/pakistan/currency } \\
\text { (accessed on } 9 \text { April 2018) }\end{array}$ \\
\hline 30 November 2018 & Exchange rate & $\begin{array}{l}\text { Further depreciation of } \\
\text { Pakistani Rupee against US } \\
\text { Dollar from132 to } 136.58\end{array}$ & $\begin{array}{l}\text { https: / / profit.pakistantoday.com.pk/2019/06/14/rupee- } \\
\text { tumbles-down-to-154-against-the-dollar/ } \\
\text { (accessed on } 9 \text { April 2018) }\end{array}$ \\
\hline 19 March 2020 & $\begin{array}{l}\text { First outbreak of } \\
\text { COVID-19 }\end{array}$ & $\begin{array}{l}\text { The first outbreak in Pakistan } \\
\text { of COVID-19 between } 11 \text { and } \\
19 \text { March }\end{array}$ & $\begin{array}{l}\text { https:/ / www.loc.gov /law / foreign-news/article/ } \\
\text { pakistan-smart-lockdown-imposed-across-cities-of- } \\
\text { pakistan-as-COVID-19-cases-grow-rapidly/ } \\
\text { (accessed on } 9 \text { April 2018) }\end{array}$ \\
\hline 23 March 2020 & $\begin{array}{l}\text { First lockdown in Karachi } \\
\text { due to COVID-19 }\end{array}$ & $\begin{array}{l}\text { First lockdown in Karachi and } \\
\text { the Pakistan stock market also } \\
\text { shut down due to COVID-19 }\end{array}$ & $\begin{array}{l}\text { https:/ / www.crisisgroup.org/asia/south-asia/pakistan/ } \\
\text { b162-pakistans-COVID-19-crisis (accessed on } 9 \text { April 2018) }\end{array}$ \\
\hline 31 May 2020 & $\begin{array}{l}\text { Nationwide lockdown } \\
\text { due to COVID-19 }\end{array}$ & $\begin{array}{l}\text { Nationwide lockdown in } \\
\text { Pakistan due to COVID-19 }\end{array}$ & $\begin{array}{l}\text { https:/ / www.crisisgroup.org/asia/south-asia/pakistan/ } \\
\text { b162-pakistans-COVID-19-crisis (accessed on } 9 \text { April 2018) }\end{array}$ \\
\hline
\end{tabular}

\section{References}

1. Sharma, G.D.; Talan, G.; Jain, M. Policy response to the economic challenge from COVID-19 in India: A qualitative enquiry. J. Public Aff. 2020, 20, e2206. [CrossRef]

2. Jaspal, R.; Assi, M.; Maatouk, I. Potential impact of the COVID-19 pandemic on mental health outcomes in societies with economic and political instability: Case of Lebanon. Ment. Health Rev. J. 2020, 25, 215-219. [CrossRef] 
3. Pak, A.; Adegboye, O.A.; Adekunle, A.I.; Rahman, K.M.; McBryde, E.S.; Eisen, D.P. Economic Consequences of the COVID-19 Outbreak: The need for epidemic preparedness. Front. Public Health 2020, 8, 1-4. [CrossRef]

4. Supoit, A. A legal perspective on the economic crisis of 2008. Int. Labour Rev. 2008, 149, 151-162. [CrossRef]

5. Sachs, J.A.M.J. Bolivia's Economic Crisis; National Bureau of Economic Research: Cambridge, MA, USA, 1988.

6. García-Sánchez, I.M.; García-Sánchez, A. Corporate social responsibility during COVID-19 pandemic. J. Open Innov. Technol. Mark. Complex 2020, 6, 126. [CrossRef]

7. Machmuddah, Z.; Utomo, S.D.; Suhartono, E.; Ali, S.; Ghulam, W.A. Stock market reaction to COVID-19: Evidence in customer goods sector with the implication for open innovation. J. Open Innov. Technol. Mark. Complex 2020, 6, 99. [CrossRef]

8. Acharya, V.V.; Schnabl, P. Do global banks spread global imbalances? Asset-backed commercial paper during the financial crisis of 2007-09. IMF Econ. Rev. 2010, 58, 37-73. [CrossRef]

9. Souiden, N.; Rani, M. Consumer attitudes and purchase intentions toward Islamic banks: The influence of religiosity. Int. J. Bank Mark. 2015, 33, 143-161. [CrossRef]

10. Opoku-Agyemang, K. Lost/gained in translation: Oware 3D, Ananse: The Origin and questions of hegemony. J. Gaming Virtual Worlds 2015, 7, 155-168. [CrossRef]

11. Adeinat, I.; Al Rahahleh, N.; Bhatti, M.I. Customer satisfaction with Ijarah financing: The mediating role of clarity and accuracy for services offered. Qual. Res. Financ. Mark. 2019, 11, 227-243. [CrossRef]

12. Fazl-E-Haider. Banking sector advancement in Pakistan. Pakistan \& Gulf Economist. 2018. Available online: https://www. pakistangulfeconomist.com/2018/04/09/banking-sector-advancement-pakistan/ (accessed on 9 April 2018).

13. Hamza, S.M.; Khan, E.A. Effect of banking sector performance in Economic growthCase study of Pakistan. J. Appl. Environ. Biol. Sci. 2014, 4, 444-449.

14. SBP. Islamic Banking Bulletin. State Bank of Pakistan. 2018. Available online: http://www.sbp.org.pk/ibd/bulletin/2018/Jun (accessed on 9 June 2018).

15. Javed, A.Y.; Ahmed, A. The Response of Karachi Stock Exchange to Nuclear Detonation. Pak. Dev. Rev. 1999, 38, 777-786. [CrossRef]

16. Khalid, S. Financial Reforms and Dynamics of Capital Structure Choice: A Case of Publically Listed Firms of Pakistan; SSRN: Rochester, NY, USA, 2010. [CrossRef]

17. Mahmood, S.; Irfan, M.; Iqbal, S.; Kamran, M.; Ijaz, A. Impact of political events on stock market: Evidence from Pakistan. J. Asian Bus. Strategy 2014, 4, 163-174.

18. Nazir, M.S.; Younus, H.; Kaleem, A.; Anwar, Z. Impact of political events on stock market returns: Empirical evidence from Pakistan. J. Econ. Adm. Sci. 2014, 30, 60-78.

19. Sohail, A.; Javid, A.Y. The Global Financial Crisis and Investors' Behaviour: Evidencefrom the Karachi Stock Exchange; PIDE-Working Papers 2014:106; Pakistan Institute of Development Economics: Islamabad, Pakistan, 2014.

20. Ahmed, F.; Syed, A.A.; Kamal, M.A.; de las Nieves López-García, M.; Ramos-Requena, J.P.; Gupta, S. Assessing the Impact of COVID-19 Pandemic on the Stock and Commodity Markets Performance and Sustainability: A Comparative Analysis of South Asian Countries. Sustainability 2021, 13, 5669. [CrossRef]

21. Azmat Saad ASMSohel Azad, M. Ishaq Bhatti, and Hamza Ghaffar. Islamic banking, costly religiosity, and competition. J. Financ. Res. 2020, 43, 263-303. [CrossRef]

22. Al Rahahleh, N.; Ishaq Bhatti, M.; Najuna Misman, F. Developments in risk management in Islamic finance: A review. J. Risk Financ. Manag. 2019, 12, 37. [CrossRef]

23. Murtaza, H.; Ali, R. Impact of major political events on stock market returns of Pakistan. Public Policy Adm. Res. 2015, 5, 68-84.

24. Ali, R.; Afzal, M. Impact of global financial crisis on stock markets: Evidence from Pakistan and India. J. Bus. Manag. Econ. 2012, 3, 275-282.

25. Draz, M.U. Impact of financial crises on Pakistan and China: A comparative study of six decades. J. Glob. Bus. Econ. 2011, 3, 174-186.

26. Ghouse, G.; Khan, S.A.; Arshad, M. Volatility Modelling and Dynamic Linkages between Pakistani and Leading Foreign Stock Markets: A Multivariate GARCH Analysis. Pak. Dev. Rev. 2019, 58, 265-282.

27. Ghouse, G.; Khan, S.A. Tracing dynamic linkages and spillover effect between Pakistani and leading foreign stock markets. Rev. Financ. Econ. 2017, 35, 29-42. [CrossRef]

28. Allvine, F.C.; O'Neill, D.E. Stock market returns and the presidential election cycle: Implications for market efficiency. Financ. Anal. J. 1980, 36, 49-56. [CrossRef]

29. Gärtner, M.; Wellershoff, K.W. Is there an election cycle in American stock returns? Int. Rev. Econ. Financ. 1995, 4, 387-410. [CrossRef]

30. Huang, R.D. Common stock returns and presidential elections. Financ. Anal. J. 1985, 41, 58-62. [CrossRef]

31. Herbst, A.F.; Slinkman, C.W. Political-economic cycles in the US stock markets. Financ. Anal. J. 1984, 40, 38-45. [CrossRef]

32. Hobbs, G.R.; Riley, W.B. Profiting from a presidential election. Financ. Anal. J. 1984, 40, 46-52. [CrossRef]

33. Niederhofer, V.; Gibbs, S.; Bullock, J. Presidential elections and the stock market. Financ. Anal. J. 1970, 26, 111-113.

34. Im, K.S.; Dow, K.E.; Grover, V. Research Report: A Reexamination of IT Investment and the Market Value of the Firm. Inf. Syst. Res. 2001, 12, 103-117. [CrossRef] 
35. Foerster, S.R.; Schmitz, J.J. The transmission of US election cycles to international stock returns. J. Int. Bus. Stud. 1997, 28, 13. [CrossRef]

36. Christos, P.; Stangeland, D.; Turtle, H. Political elections and the resolution of uncertainty: The international evidence. J. Bank. Financ. 2000, 24, 1575-1604.

37. Riley, W.B.; Luksetich, W.A. The market prefers Republicans: Myth or reality. J. Financ. Quant. Anal. 1980, 15, 541-560. [CrossRef]

38. Bremmer, I. Managing risk in an unstable world. Harv. Bus. Rev. 2005, 83, 51-58.

39. Henisz, W.J.; Zelner, B.A. The hidden risks in emerging markets. Harv. Bus. Rev. 2010, 88, 88-95. [CrossRef]

40. Lehkonen, H.; Heimonen, K. Democracy, political risks and stock market performance. J. Int. Money Financ. 2015, 59, 77-99. [CrossRef]

41. Giambona, E.; Graham, J.R.; Harvey, C.R. The management of political risk. J. Int. Bus. Stud. 2017, 48, 523-533. [CrossRef]

42. Bekaert, G.; Harvey, C.R.; Lundblad, C.T.; Siegel, S. Political risk spreads. J. Int. Bus. Stud. 2014, 45, 471-493. [CrossRef]

43. Julio, B.; Yook, Y. Political uncertainty and corporate investment cycles. J. Financ. 2012, 67, 45-82. [CrossRef]

44. Vaaler, P.; Schrage, B.; Block, S. Counting the investor vote: Political business cycle effects on sovereign bond spreads in developing countries. J. Int. Bus. Stud. 2005, 36, 62-88. [CrossRef]

45. Darendeli, I.; Hill, T. Uncovering the complex relationships between political risk andMNE firm legitimacy: Insights from Libya. J. Int. Bus. Stud. 2016, 47, 68-92. [CrossRef]

46. Globerman, S.; Shapiro, D. Governance infrastructure and US foreign direct investment. J. Int. Bus. Stud. 2003, 34, 19-39. [CrossRef]

47. Li, Q.; Resnick, A. Reversal of fortunes: Democratic institutions and foreign direct investment inflows to developing countries. Int. Organ. 2003, 57, 175-211. [CrossRef]

48. Habib, M.; Zurawicki, L. Corruption and foreign direct investment. J. Int. Bus. Stud. 2002, 33, 291-307. [CrossRef]

49. Uhlenbruck, K.; Rodriguez, P.; Doh, J.; Eden, L. The impact of corruption on entry strategy: Evidence from telecommunication projects in emerging economies. Organ. Sci. 2006, 17, 402-414. [CrossRef]

50. Wei, S. How taxing is corruption on international investors? Rev. Econ. Stat. 2000, 82, 1-11. [CrossRef]

51. Brogaard, J.; Dai, L.; Ngo, P.; Zhang, B. The World Price of Political Uncertainty; Working paper; University of Washington: Washington, DC, USA, 2014.

52. Loree, D.; Guisinger, S. Policy and non-policy determinants of U.S. equity foreign direct investment. J. Int. Bus. Stud. 1995, 26, 281-299. [CrossRef]

53. Sethi, D.; Guisinger, S.; Phelan, S.; Berg, D. Trends in foreign direct investment flows: A theoretical and empirical analysis. J. Int Bus. Stud. 2003, 34, 315-326. [CrossRef]

54. Alfaro, L.; Kalemli-Ozcan, S.; Volosovych, V. Why doesn't capital flow from rich topoor countries? An empirical investigation. Rev. Econ. Stat. 2008, 90, 347-368. [CrossRef]

55. Bekaert, G.; Harvey, C.R.; Lundblad, C.T.; Siegel, S. Global growth opportunities and market integration. J. Financ. 2007, 62, 1081-1137. [CrossRef]

56. Bilson, C.M.; Brailsford, T.J.; Hooper, V.C. The explanatory power of political risk in emerging markets. Int. Rev. Financ. Anal. 2002, 11, 1-27. [CrossRef]

57. Diamonte, R.L.; Liew, J.M.; Stevens, R.L. Political risk in emerging and developed markets. Financ. Anal. J. 1996, 52, 71-76. [CrossRef]

58. Erb, C.B.; Harvey, C.R.; Viskanta, T.E. Political risk, economic risk, and financial risk. Financ. Anal. J. 1996, 52, 29-46. [CrossRef]

59. Belkhir, M.; Boubakri, N.; Grira, J. Political risk and the cost of capital in the MENA region. Emerg. Mark. Rev. 2017, 33, 155-172. [CrossRef]

60. Butler, K.C.; Joaquin, D.C. A note on political risk and the required return of foreigndirect investment. J. Int. Bus. Stud. 1998, 29, 599-607. [CrossRef]

61. Dimic, N.; Orlov, V.; Piljak, V. The political risk factor in emerging, frontier, and developed stock markets. Financ. Res. Lett. 2015, 1, 239-245. [CrossRef]

62. Grira, J.; Hassan, M.K.; Soumaré, I. Pricing beliefs: Empirical evidence from the implied cost of deposit insurance for Islamic banks. Econ. Model. 2016, 55, 152-168. [CrossRef]

63. Perotti, E.C.; Oije, V.P. Privatization, political risk and stock market development in emerging economies. J. Int. Money Financ. 2001, 20, 43-69. [CrossRef]

64. Bekiros, S.D. Contagion, decoupling and the spillover effects of the US financial crisis: Evidence from the BRIC markets. Int. Rev. Financ. Anal. 2014, 33, 58-69. [CrossRef]

65. Kenourgios, D.; Christopoulos, A.G.; Dimitriou, D.I. Asset markets contagion during the global financial crisis. Multinatl. Financ. J. 2013, 17, 49-76. [CrossRef]

66. Kenourgios, D.; Samitas, A.; Paltalidis, N. Financial crises and stock market contagion in a multivariate time-varying asymmetric framework. J. Int. Financ. Mark. Inst. Money 2011, 21, 92-106. [CrossRef]

67. Luchtenberg, K.F.; Vu, Q.V. The 2008 financial crisis: Stock market contagion and its determinants. Res. Int. Bus. Financ. 2015, 33, 178-203. [CrossRef]

68. Yarovaya, L.; Brzeszczyński, J.; Lau, C.K.M. Intra-and inter-regional return and volatility spillovers across emerging and developed markets: Evidence from stock indices and stock index futures. Int. Rev. Financ. Anal. 2016, 43, 96-114. [CrossRef] 
69. Mobarok, M.H.; Thompson, W.; Skevas, T. COVID-19 and Policy Impacts on the Bangladeshi Rice Market and Food Security. Sustainability 2021, 13, 5981. [CrossRef]

70. Harvey, C.R.; Liu, Y. False (and missed) discoveries in financial economics. J. Financ. 2020, 75, 2503-2553. [CrossRef]

71. Engle, R.F. Autoregressive Conditional Heteroscedasticity with Estimates of the Variance of United Kingdom Inflation. Econometrica 1982, 50, 987-1007. [CrossRef]

72. Bollerslev, T. Generalized Autoregressive Conditional Heteroskedasticity. J. Econom. 1986, 31, 307-327. [CrossRef]

73. Johansen, S.; Hendry, D.F.; Santos, C. Selecting a regression saturated by indicators. CREATES Res. Pap. 2007, 36, 1-19. [CrossRef] 